\title{
Enhancing job satisfaction through work-family enrichment and
perceived supervisor support: the
case of Australian social workers
} AQ: 4

Enhancing job satisfaction through work

\author{
Parveen Kalliath
}

School of Allied Health, Australian Catholic University - Canberra Campus,

AQ: 2

Watson, Australia

Thomas Kalliath

Research School of Management, Australian National University, Sydney, Australia Xi Wen Chan

College of Business, RMIT University, Melbourne, Australia

Christopher Chan

Faculty of Law and Business, Australian Catholic University, Melbourne,

Australia, and

AQ: 1

Christopher Chan

Institut de Gestion de Rennes, Université de Rennes, Rennes, France

\begin{abstract}
Purpose - Drawing on the conservation of resources theory and social exchange theory, this study aims to examine the underlying relationships linking work-to-family enrichment (WFE) and family-to-work enrichment (FWE) to perceived supervisor support and ultimately, job satisfaction among social workers.

Design/methodology/approach - Data were collected from members of a social work professional body $(n=439)$ through an internet-based questionnaire and analysed using confirmatory factor analysis and structural equation modelling.

Findings - Perceived supervisor support mediated the relationships between work-family enrichment (specifically, WFE-Development, WFE-Affect and FWE-Efficiency) and job satisfaction.

Research limitations/implications - Social workers who worked in a positive work environment that uplifts their moods and attitudes (WFE-Affect), have access to intellectual and personal development (WFEDevelopment) and felt supported by their supervisors reported higher levels of job satisfaction. Those who possessed enrichment resources were found to be more efficient (FWE-Efficiency) also perceived their supervisors to be supportive and experienced higher job satisfaction. Future studies should consider other professional groups and incorporate a longitudinal design.

Practical implications - Promoting work-family enrichment among social workers can contribute to positive work outcomes such as perceived supervisor support and job satisfaction. HR practitioners, supervisors and organisations can promote work-family enrichment among social workers through introduction of family-friendly policies (e.g. flexitime, compressed workweek schedules) and providing a supportive work-family friendly environment for social workers.

Originality/value - Although several work-family studies have linked work-family enrichment to job satisfaction, the present study shows how each dimension of WFE and FWE affects social workers' job satisfaction.
\end{abstract}

Keywords Quantitative, Job satisfaction, Advanced statistical, Supervisor support, Quantitative research, Work-life balance

Paper type Research paper

\section{Introduction}

Few studies have investigated the work-family experiences of social workers and how these experiences impact on their job satisfaction (Baum, 2016; Kalliath, 2014; Kalliath and Kalliath,

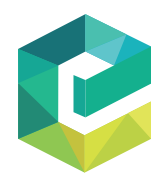

Personnel Review (c) Emerald Publishing Limited 0048-3486
Received 21 June 2018 Revised 17 January 2019 26 April 2019

13 November 2019 Accepted 16 February 2020 

(e.g. Kalliath and Kalliath, 2015; Kalliath et al., 2015; Lambert et al., 2006) have drawn attention to the challenges for social workers to meet competing work and family demands and their reduced job satisfaction and increased psychological strain due to work-family conflict. The HR and social work literature has also repeatedly highlighted the stress experienced by social workers from regular exposure to client trauma and other organisational pressures (Baum, 2016; Huxley et al., 2005). Despite the demands and challenges associated with social work practice, Collins (2008) reported that social workers derive fulfilment and satisfaction from their work that can enhance experiences in the family and contribute to work-family enrichment (Greenhaus and Powell, 2006). Further studies (e.g. Kalliath, 2014) have shown that, while competing work and family demands can adversely affect social workers, the resources generated from participation in either work or family roles can enhance and enrich the quality of life in both roles (see Au and Ahmed, 2016; Chan et al., 2016). The present study aimed to investigate the role of work-family enrichment and perceived supervisor support at work in enhancing social workers' job satisfaction.

Job satisfaction is defined as "a pleasurable or positive emotional state resulting from the appraisal of one's job or job experiences” (Locke, 1976, p. 1304). There has been much debate on job satisfaction in the social work profession because of its impact on retention and turnover of social workers (Egan and Kadushin, 2004; Calitz et al., 2014), which disrupts the provision of services by social service agencies (Freund, 2005). The majority of research on job satisfaction has focused on job stress, burnout or work-family conflict (Calitz et al., 2014; Schwartz, 2007). The positive aspects of social work, such as work-family enrichment, are often overlooked in the literature, although work-family enrichment can outweigh the potential for stress because they build strengths and enhance the optimal functioning of social workers (Kalliath et al., 2019; McNall et al., 2010).

The most cited definition of work-family enrichment by Greenhaus and Powell (2006, p. 72) defines it as "the extent to which experiences in one role (work or family) improve the quality of life in the other role". The pathways for enrichment to occur can be from workto-family (WFE) and from family-to-work (FWE). WFE is experienced when resources gained from work participation can be used productively in the family for better quality of family life. FWE is experienced when resources gained from participation in family life enhance performance at work. While several work-family studies (e.g. Carlson et al., 2014; Chan et al., 2016) have linked WFE and FWE to job satisfaction in different professions, little is known about how enrichment affects this outcome for social workers. Correspondingly, this study examined the six dimensions of WFE and FWE (explained in the following paragraph) to understand which role experiences influence social workers' job satisfaction.

Informed by Greenhaus and Powell's (2006) conceptualisation of work-family enrichment, Carlson et al. (2006) developed an 18-item scale to measure the six dimensions of work-family enrichment. These include: WFE and FWE-Development, which occurs when knowledge and skills gained from one domain (work or family), improve performance in another domain, contributing to enhancement of personal and intellectual development; WFE and FWEAffect occurs when positive moods and attitudes originating in one domain benefit another domain; WFE-Capital refers to benefits such as a sense of accomplishment or self-esteem that are acquired from the workplace and are effectively used to improve performance in the family; and FWE-Efficiency, refers to benefits gained from the family domain that are used to improve performance in the work domain. Carlson et al.'s (2006) conceptualisation of workfamily enrichment captures the positive mechanisms of the work-family interface and facilitates better understanding of work-family linkages.

This study also investigated perceived supervisor support as a mediator of the relationships between WFE, FWE and job satisfaction. Perceived supervisor support refers 
to subordinates' perceptions of the level of support they receive from their supervisors. Without supervisor support, stressful work demands, situations and environments can potentially harm the overall wellbeing of social workers (Offer and Schneider, 2008). The perception and role of supervisor support was emphasised in Collins' (2008) study, in which perceived social support was one of the primary coping mechanisms. Drawing on Hobfoll's $(1989,2001)$ conservation of resources (COR) theory and Blau's (1964) social exchange theory, this study sought to: examine whether WFE-Development, FWE-Development, WFE-Affect, FWE-Affect, WFE-Capital and FWE-Efficiency are associated with job satisfaction and determine whether perceived supervisor support acts as a mediator linking each dimension of

F1 WFE and FWE to job satisfaction (Figure 1).

\section{Theoretical and empirical basis for the study}

Theorising work-family enrichment

Sieber (1974) and later Marks (1977) argued that participating in multiple roles does not result in detrimental consequences; rather, multiplicity of roles, or role accumulation, can be advantageous for performance in both the work and family domains. For example, a social worker may acquire multi-tasking and time-management skills at home, which can be used effectively in work situations. Likewise, skills in mediation or conflict resolution acquired at work can be used to resolve conflict situations at home. Based on this understanding, Greenhaus and Powell's (2006) theory of work-family enrichment proposes that enrichment occurs via two pathways: the instrumental pathway involves resources obtained from one role that directly promote higher performance in another role, and the affective pathway includes resources obtained from one role, which indirectly facilitate functioning and performance in another role, and is normally accompanied with positive emotions. Resources

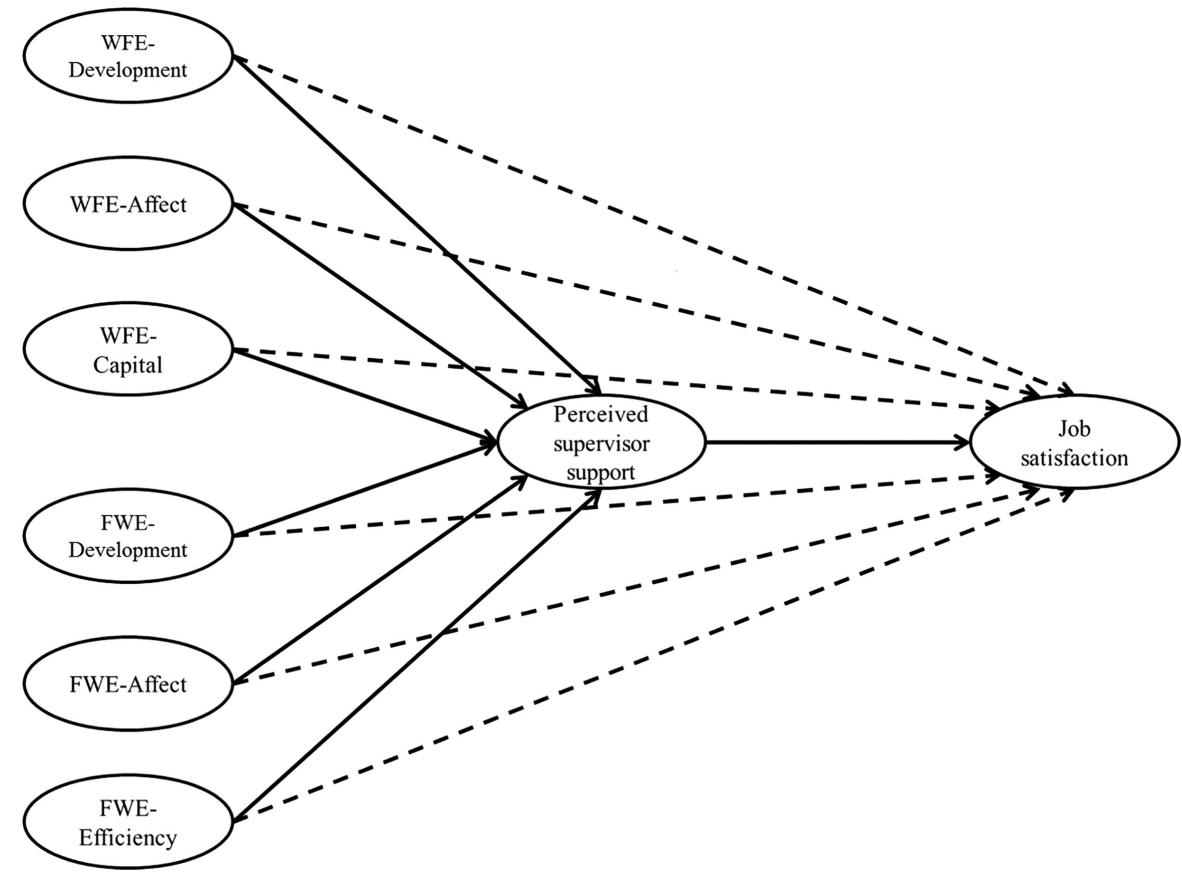

Figure 1.

Hypothesised mediation model

PR — PR-06-2018-0219_proof — 16 April 2020 — 11:13 am 
may refer to skills such as communication and coping skills, psychological and physical resources (e.g. self-esteem and health), social-capital resources (e.g. networks and influence) or material resources (e.g. money) (Halbesleben et al., 2014). In general, resources enable individuals to adapt to and cope with stressful situations and benefit from opportunities (Carlson et al., 2014).

\section{Association between work-family enrichment and job satisfaction}

Job satisfaction is commonly recognised as "the most focal employee attitude" (Saari and Judge, 2004, p. 396); hence, this study investigated how work-family enrichment fosters job satisfaction for social workers. While role accumulation forms the basis for the mechanisms underpinning work-family enrichment, the social exchange theory and COR theory provide richer insights into how enrichment influences job satisfaction. Based on the key tenets of the social exchange theory, it is argued that when social workers perceive their work environments to be supportive in managing their work and family responsibilities, they are more likely to feel cared for (Aryee et al., 2005). Consequently, as a gesture of reciprocity (Blau, 1964), they may return the favour through positive job-related feelings, attitudes and behaviours. Further, Wayne et al. (2007) found that individuals make cognitive attributions towards the source of benefits, such that when a domain (e.g. work) is perceived to be providing resources that benefit the receiving domain (e.g. family), the individual experiences satisfaction with the originating domain (e.g. the work domain).

To examine each dimension of WFE and FWE in more detail, as well as how they relate to job satisfaction, the COR theory was also utilised. The COR theory is based on the premise that individuals are motivated to conserve their existing resources and acquire additional resources. A lack of resources tends to lead to further resource depletion (loss cycle), while having or gaining resources is more likely to lead to further resource gain (gain spiral) (Hobfoll, 2001). Additionally, people tend to utilise the resources they already possess to acquire additional resources creating "resource caravans", which act as buffers during difficult times and facilitate better coping (Hobfoll, 2002).

Similar to the theory of work-family enrichment, the COR theory defines resources as personal characteristics (e.g. sense of optimism), objects (e.g. a vehicle), conditions (e.g. marriage), energies (e.g. physical energy) and other things that people value (Halbesleben et al., 2014). Hobfoll (2002) further distinguished between contextual resources (e.g. familyfriendly workplace), which are found in the social contexts of the individual, and personal resources (e.g. self-percept, energies), which are internal to the individual (Hobfoll, 2002). This distinction enables us to understand how social workers utilise environmental resources to achieve positive states (e.g. well-being) and goals (ten Brummelhuis and Bakker, 2012).

The aforementioned loss and gain processes postulated by the COR theory can be applied to the work-family interface. Work-family enrichment is the process whereby resources from work and family domains facilitate performance within these domains and contribute in the development of personal resources (Siu et al., 2010; ten Brummelhuis and Bakker, 2012). For example, a workplace that provides social workers opportunities for them to develop professionally (WFE-Development), provides them support to achieve their professional and personal goals (WFE-Capital) and provides for a work environment where positive affect is experienced (WFE-Affect) will facilitate their engagement at work and ultimately increase their job satisfaction (Dollard and Bakker, 2010). This is also consistent with the second assumption of the COR theory, which posits that resources can generate new resources such that the resources obtained create a gain spiral for resources to accumulate (Hobfoll, 2001), which subsequently enhance performance and well-being in the family domain (Oerlemans et al., 2014). 
A few studies have examined how work-family enrichment contributes to the overall well-being, including job satisfaction, of social workers. Kalliath's (2014) social work study reported that participation in work and family roles was associated with reduced psychological strain. Other studies (e.g. Carlson et al., 2014; Chan et al., 2016; Hammer et al., 2005) using non-social worker samples have reported that both WFE and FWE contribute to increased job satisfaction. By definition, when participation in work and family roles enriches involvement in these domains through the acquisition of resources, then performance, behaviours and attitudes should improve such that job satisfaction is increased. Based on these premises, the study hypothesises that:

H1a. WFE-Development, WFE-Affect and WFE-Capital will be positively related to job satisfaction.

H1b. FWE-Development, FWE-Affect and FWE-Efficiency will be positively related to job satisfaction.

Perceived supervisor support and its mediating role

Supervisors play a vital role in influencing their employees' attitudes, expectations and behaviours (Griffin et al., 2001; Rathi and Lee, 2017). Supervisor support is a major source of support for social workers, as they often consult their supervisors for assistance with administrative issues, clinical cases and further skills development (Hughes, 2010; Lloyd et al., 2002). Supervisor support has been found to be associated with lower levels of burnout, work stress and mental health problems among social workers (Beddoe et al., 2015; Hughes, 2010). Perceived supervisor support reflects employees' perceptions that their supervisors value their contributions and are concerned about their well-being (Shanock and Eisenberger, 2006). Supervisors are agents in organisations responsible for guiding employees and directing their performance; thus, employees perceive their supervisors' orientation towards them as indicative of supervisor and organisational support (Shanock and Eisenberger, 2006). Therefore, most researchers assess supervisor support with perceived supervisor support.

Supervisors can afford a variety of valued resources, including greater attention, monetary support and emotional support. Subordinates may perceive their supervisors as supportive after observing their supervisors granting resources they value. The accumulation of contextual resources (e.g. WFE-Development, WFE-Affect, WFE-Capital, FWE-Development, FWE-Affect and FWE-Efficiency) is also associated with positive feelings about general workplace and supervisor support (Dollard and Bakker, 2010). Correspondingly, social workers who experience WFE-Development, WFE-Affect, WFECapital, FWE-Development, FWE-Affect and FWE-Efficiency are more likely to perceive their supervisors as being supportive and appreciative of their work and contributions to the workplace. In fact, several studies (e.g. Baral and Bhargava, 2010; Cinamon and Rich, 2010) have found that WFE is associated with perceived supervisor support. Additionally, emotional support experienced by employees can reverberate in other workers and promote a supportive work climate, which fosters job satisfaction (Siu et al., 2010). Therefore, based on these findings and in line with the resource acquisition and gain spiral propositions of the COR theory, the current research also hypothesises that:

H2a. Perceived supervisor support will mediate the relationships between all three dimensions of WFE (WFE-Development, WFE-Affect and WFE-Capital) and job satisfaction.

H2b. Perceived supervisor support will mediate the relationships between all three dimensions of FWE (FWE-Development, FWE-Affect and FWE-Efficiency) and job satisfaction. 


\section{Research design}

Participants and procedures

Participants were members of a social work professional body. Following ethics approval, self-report data were collected using an online questionnaire, which was forwarded by the professional body to approximately 2,000 members in Australia. Participants were in full- or part-time employment. In total, 448 completed questionnaires (22.5 per cent response rate) were received, of which 439 yielded useable data (22.0 per cent response rate). The nine cases ( 0.45 per cent) were deleted using list-wise deletion due to the presence of multiple missing data. The response rate was calculated conservatively, as it was difficult to ascertain how many social workers had received the online questionnaire.

Most participants (81.1 per cent) were female, which is consistent with the percentage of women (78.3 per cent) working in healthcare and human services in Australia (Australian Bureau of Statistics, 2016). The mean age was 44.1 years (range 23.0-69.0 years). Most of the participants (69.7 per cent) were in a partnered relationship (married or cohabitating), and 29.5 per cent of the participants were single, separated, divorced or widowed. About 54 percent reported having no children. Of those with children ( 46.6 per cent), the mean age of the children was 13.9 years. The demographic profile of the sample is comparable to that of the Australian social work workforce reported by Healy and Lonne (2010). A majority (74.0 per cent) of the participants had a Bachelor of Social Work qualification, and 71.0 per cent of the participants were in full-time employment working an average of $36.7 \mathrm{~h}$ per week. This is consistent with global trends in the length of the work week in developed countries (Rogerson, 2006). Most of the participants (66.3 per cent) were in social work practice, while the others were in supervisory/management (24.8 per cent) or tertiary education roles (5.9 per cent). In addition, 20 per cent of the participants provided care to up to three extended family members. Lastly, 50.0 per cent reported having partners who worked full-time.

\section{Research measures}

Work-to-family enrichment and family-to-work enrichment. The 18-item work-family enrichment scale was used for measuring WFE and FWE (Carlson et al., 2006). Example items include: (1) My involvement in my work "helps me to gain knowledge and this helps me be a better family member" (WFE-Capital), "makes me feel happy and this helps me be a better family member" (WFE-Affect) and "provides me with a sense of accomplishment and this helps me be a better family member" (WFE-Development); (2) My involvement in my family "helps me to acquire skills and this helps me be a better worker" (FWE-Development), "makes me feel happy and this helps me be a better worker" (FWE-Affect) and "requires me to avoid wasting time at work and this helps me be a better worker" (FWE-Efficiency). Participants responded on a five-point Likert scale which ranged from1 = "strongly disagree" to $5=$ "strongly agree". Cronbach's alphas for these scales were in the range of 0.92-0.96.

Perceived supervisor support. Perceived supervisor support was measured using the fouritem scale developed by Caplan et al. (1980). A sample item includes: "My supervisor is willing to listen to my personal problems". Responses were measured on a five-point Likert scale ranging from $1=$ "strongly disagree" to 5 = "strongly agree". Cronbach's alpha for this scale was 0.92 .

Job satisfaction. A three-item scale adapted from the Michigan Organisational Assessment Questionnaire measured job satisfaction (O'Driscoll, 2000; Seashore et al., 1982). A sample item includes: "I enjoy what I do in my job". Participants responded on a seven-point Likert scale which ranged from 1 = "strongly disagree" to 7 = "strongly agree". Cronbach's alpha for this scale was 0.92 .

Drawing on prior studies (e.g. Chan et al., 2016; Cheng et al., 2014; Henry and Desmette, 2018; Rastogi and Chaudhary, 2019), which suggest that demographic variables such as age, 
gender, marital status, tenure and hours worked per week may affect individuals' job satisfaction due to the potential for work-family enrichment, the study controlled for age, gender $(0=$ male, $1=$ female $)$, age, marital status $(0=$ single or not married, $1=$ divorced or separated and $2=$ married or cohabiting), number of dependent children, years of experience, type of employment $(0=$ social work practice, $1=$ supervisory/management and $2=$ tertiary institution) and hours worked per week.

\section{Data analyses}

Confirmatory factor analysis (CFA) (AMOS version 24.0) and reliability analysis (SPSS version 24.0) were used for assessing the psychometric properties of the measures. The hypotheses were subsequently tested using structural equation modelling (SEM) (AMOS version 24.0). Fit indices such as normed chi-square, goodness-of-fit index (GFI), adjusted GFI (AGFI), incremental fix index (IFI), Tucker-Lewis index (TLI), comparative fit index (CFI) and root mean square error of approximation (RMSEA) were used in CFA and SEM to assess the model fit (Hu and Bentler, 1999). The values for GFI, AGFI, IFI, TLI and CFI are between 0 and 1 , with values of at least 0.90 representing a good-fitting model. Additionally, a RMSEA of less than 0.08 is indicative of good fit. Lastly, a normed chi-square of less than 2 indicates good fit (Ullman, 2001).

Informed by the two-step procedure proposed by Anderson and Gerbing (1988), CFA was first conducted to estimate the measurement model and determine its discriminant validity. When conducting CFA, eight latent variables were specified: WFE-Capital, WFEAffect, WFE-Development, FWE-Development, FWE-Affect, FWE-Efficiency, job satisfaction and perceived supervisor support. The fit indices (normed chi-square $=1.52$, $\mathrm{GFI}=0.93, \mathrm{AGFI}=0.90, \mathrm{IFI}=0.98, \mathrm{TLI}=0.98, \mathrm{CFI}=0.98, \mathrm{RMSEA}=0.03$ ) for the sample indicated good fit. Next, a second-order factor was specified for WFE-Capital, WFEAffect and WFE-Development, and another second-order factor was specified for FWEDevelopment, FWE-Affect and FWE-Efficiency. These two second-order factors were tested with job satisfaction and perceived supervisor support. The fit indices of the four-factor model had poor fit (normed chi-square $=13.50$, GFI $=0.57$, AGFI $=0.48$, $\mathrm{IFI}=0.70$, $\mathrm{TLI}=0.67$, RMSEA $=0.17$ ). A one-factor model for the sample was then tested to confirm whether one factor could provide a better fit. The fit indices of the one-factor model (normed chi-square $=27.50, \mathrm{GFI}=0.39, \mathrm{AGFI}=0.27, \mathrm{IFI}=0.38, \mathrm{TLI}=0.32, \mathrm{CFI}=0.38$, RMSEA $=0.25)$ for the sample indicated poor fit. Thus, the eight-factor model explained the model better.

The hypothesised structural model was subsequently tested using SEM. Similarly, the fit indices (normed chi-square $=1.51$, GFI $=0.93$, AGFI $=0.90, \mathrm{IFI}=0.98$, TLI $=0.98$, $\mathrm{CFI}=0.98$, RMSEA $=0.03$ ) for the sample indicated good fit. The mediating effects of perceived supervisor support on all the WFE-job satisfaction and FWE-job satisfaction relationships were tested using the bootstrapping method with 5,000 iterations, which enabled determination of the effect sizes (Cheung, 2009). This newer approach by Preacher and Hayes (2008) for testing the mediation effects is a development of the classical mediation approach by Baron and Kenny (1986). An independent sample $t$-test was also performed on the sample variables based on early and late responses. No significant difference was found between the early and late responses.

\section{Results}

T1 Table 1 provides the means, standard deviations, scale reliabilities and correlations of the examined variables. The correlation coefficients in Table 1 show that most variables were significant and, in the direction, expected. For example, there were positive and significant 
PR

Table 1.

Means, standard deviations, scale alphas and correlation coefficients

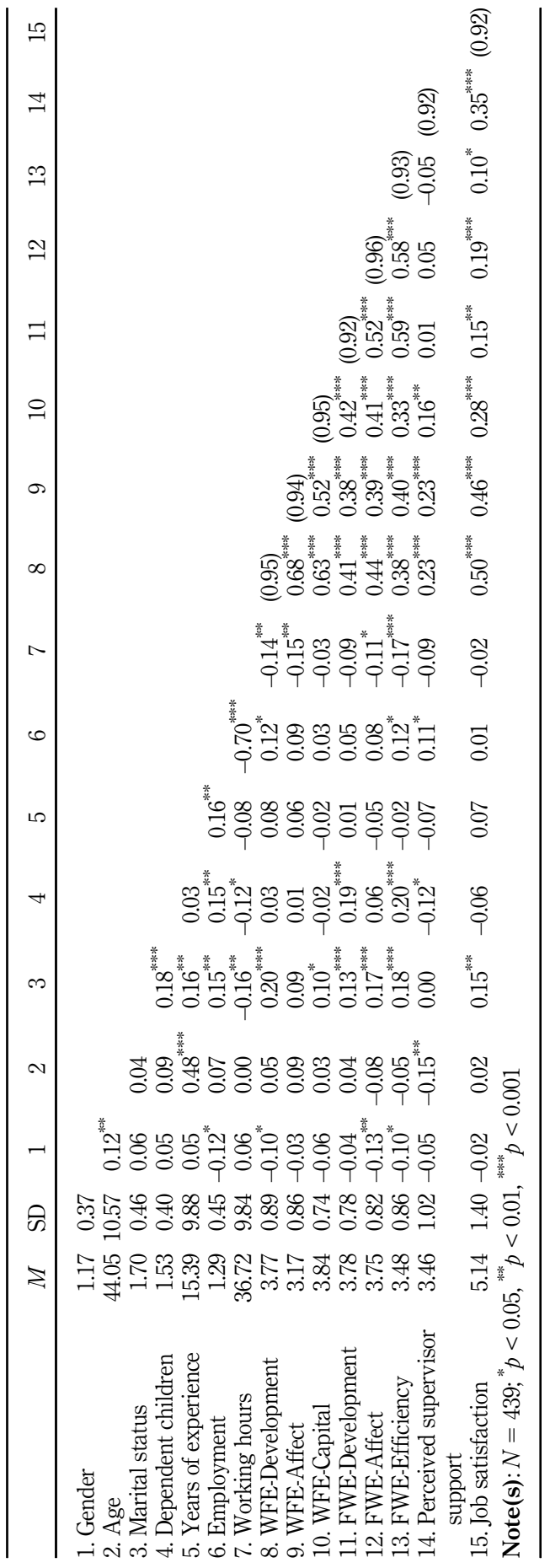


correlations between WFE-Development, WFE-Affect, WFE-Capital, FWE-Development, FWE-Affect and FWE-Efficiency and job satisfaction. WFE-Development, WFE-Affect and WFE-Capital were also positively and significantly correlated to perceived supervisor support. FWE-Development, FWE-Affect and FWE-Efficiency were not significantly correlated to perceived supervisor support. Finally, perceived supervisor support was positively and significantly correlated to job satisfaction.

The SEM results (Table 2 ) showed that WFE-Development $(\beta=0.37, p<0.001)$ and WFEAffect $(\beta=0.25, p<0.001)$ were significantly and positively related to job satisfaction. None of the FWE variables was significantly related to job satisfaction. These results indicate that H1a was partially supported, while H1b was not supported. To evaluate the overall mediation effects, we obtained the results for the overall and standardised bootstrapped coefficients. Perceived supervisor support partially mediated the relationship between WFEDevelopment and job satisfaction (bootstrapped $\beta=0.04, p<0.05$ ) and WFE-Affect and job satisfaction (bootstrapped $\beta=0.04, p<0.01$ ) and fully mediated the relationship between FWE-Efficiency and job satisfaction (bootstrapped $\beta=-0.04, p<0.01$ ). Correspondingly, $\mathrm{H} 2 \mathrm{a}$ and $\mathrm{H} 2 \mathrm{~b}$ received partial support.

F2 Figure 2 depicts the relationships in the model.

\section{Discussion of findings}

Informed by the key tenets of the COR theory and social exchange theory, the present study examined the influence of work-family enrichment on job satisfaction through the mediating effects of perceived supervisor support for social workers in Australia. This study contributes to the growing literature on the positive aspects of the work-family interface, and more specifically, introduces positive psychology to investigate the work-family experiences of social workers. To the best of the authors' knowledge, the present study is among only a few studies (e.g. Kalliath, 2014; Kalliath et al., 2019) that have examined social workers' workfamily enrichment and how it affects their job satisfaction. Additionally, this study is among

\begin{tabular}{lcrr}
\hline Variables & Model 1 & Model 2 & Model 3 \\
\hline Controls & & & 0.00 \\
Gender & -0.04 & 0.00 & 0.01 \\
Age & 0.02 & -0.03 & $0.09^{*}$ \\
Marital status & $0.15^{* *}$ & $0.09^{*}$ & -0.03 \\
Number of dependent children & -0.09 & -0.04 & 0.03 \\
Years of experience & 0.04 & 0.02 & -0.05 \\
Employment & -0.03 & -0.02 & 0.05 \\
Working hours & -0.02 & 0.05 & $0.37^{* * *}$ \\
Direct effects & & & $0.25^{* * *}$ \\
WFE-Development & & $0.40^{* * *}$ & -0.10 \\
WFE-Affect & & $0.31^{* * *}$ & -0.01 \\
WFE-Capital & & -0.10 & 0.02 \\
FWE-Development & & 0.00 & -0.11 \\
FWE-Affect & & 0.02 & $-0.16^{*}$ \\
FWE-Efficiency & & &
\end{tabular}

Mediator

Supervisor support

Note(s): $N=439 ;{ }^{*} p<0.05,{ }^{* *} p<0.01,{ }^{* * *} p<0.001$; Model 1 shows the direct effects of the control variables on job satisfaction; Model 2 shows the direct effects of the control variables and work-family enrichment variables on job satisfaction; Model 3 shows the full mediation model, which includes the mediating effects of perceived supervisor support
Enhancing job satisfaction through work 
PR

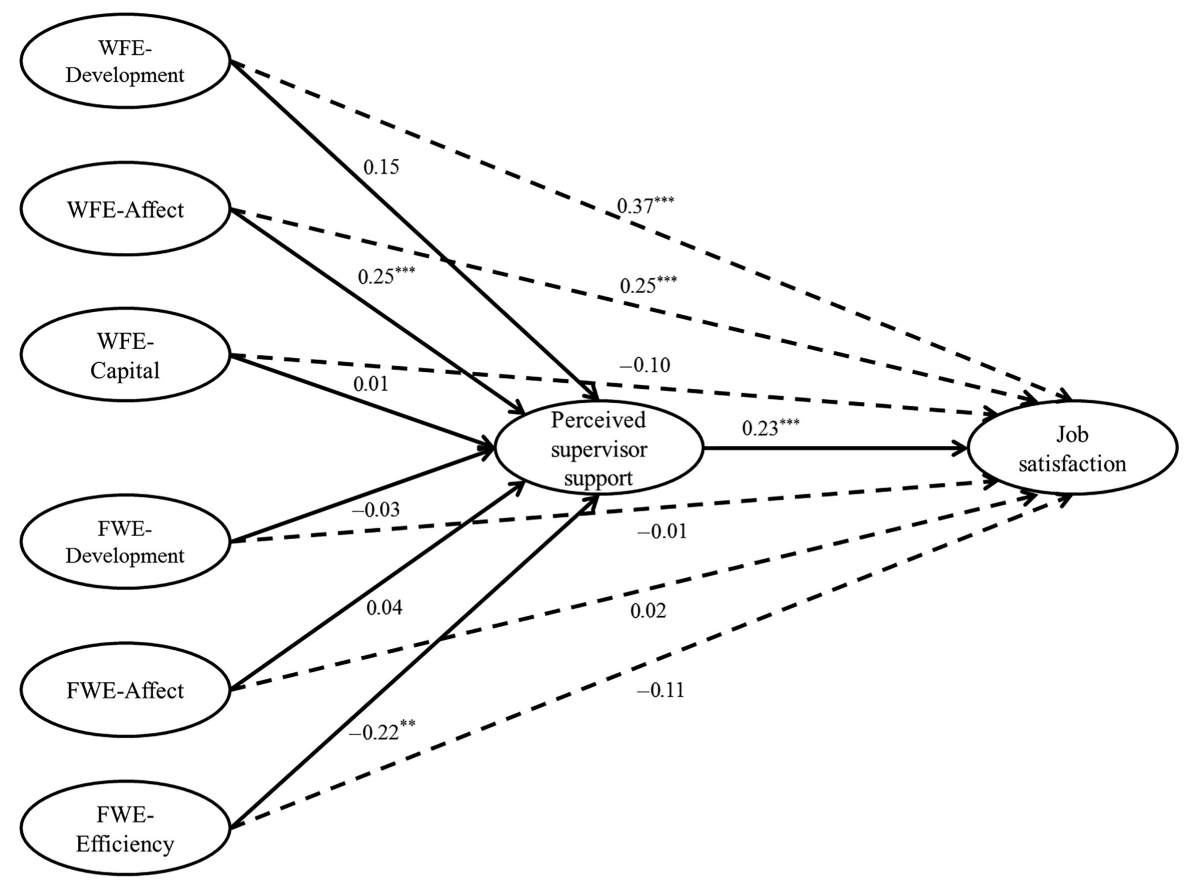

Figure 2.

SEM results

Note(s): $N=439 ;{ }^{*} p<0.05,{ }^{* *} p<0.01,{ }^{* * *} p<0.001$; Solid lines represent the direct relationships between the variables; Dotted lines represent the direct effects of work-family enrichment on job satisfaction

a few studies that have examined the relationships between each dimension of work-family enrichment (Carlson et al., 2006) and job satisfaction. Therefore, the current research represents an important step in understanding work-family enrichment in more detail, as well as the work-family experiences of social workers and how they affect job satisfaction, a work outcome.

Although McNall et al.'s (2010) meta-analysis of the outcomes associated with workfamily enrichment showed that all dimensions of WFE and FWE were positively related to job satisfaction, in the present study, only certain work-family variables (WFEDevelopment, WFE-Affect, FWE-Efficiency) were significantly related to job satisfaction, although FWE-Efficiency was negatively related to job satisfaction. Based on the resource acquisition and gain spiral propositions of the COR theory, this study also found that perceived supervisor support mediated the relationships between certain dimensions of work-family enrichment (WFE-Development, WFE-Affect and FWE-Efficiency) and job satisfaction. The relationships between WFE-Development and job satisfaction and WFEAffect and job satisfaction remained significant even after perceived supervisor support was included as a mediator. Thus, perceived supervisor support partially mediated the relationships between WFE-Development and job satisfaction and WFE-Affect and job satisfaction. By contrast, the direct relationship between FWE-Efficiency and job satisfaction became insignificant after perceived supervisor support was included as a mediator. Hence, perceived supervisor support fully mediated the FWE-Efficiency and job satisfaction relationship. At the same time, this study found that perceived supervisor support did not mediate the relationships between the other dimensions of enrichment (WFE-Capital, 
FWE-Development and FWE-Affect) and job satisfaction. These mixed findings will be discussed in the next section.

\section{Theoretical implications}

Two dimensions of WFE (i.e. WFE-Development and WFE-Affect) were positively and one dimension of FWE (i.e. FWE-Efficiency) was negatively related to job satisfaction. The WFE-job satisfaction relationships also remained significant after perceived supervisor support was included as a mediator in the data analyses. Although the relationships between the two WFE variables and job satisfaction are consistent with the findings in McNall et al. (2010) meta-analysis and Wayne et al.'s (2007) study, FWE-Efficiency was negatively related to job satisfaction, which was contrary to our expectation and the extant literature. This can be explained by the social exchange theory, as individuals tend to reciprocate in the form of more favourable attitudes towards the originating domain of resource generation. It could also be that social workers, like many other working professionals, continue to prioritise work over family (Kossek et al., 2011). Additionally, it may be worth considering gendered workplace experiences that may relate to work-family relationships; especially because the study's sample was over represented by women. Women continue to experience a lack of access to flexible jobs that allow alignment of work and family responsibilities (Kossek, 2015). Further, social roles are organised such that women are more likely than men to be homemakers and primary caretakers of children and to hold caretaking jobs in the paid economy (Eagly and Wood, 2016; Williams, 2001). Hence, the efficiency gained from the family-home interface might be promoting stressors that affect job satisfaction, especially when family demands may be perceived to clash with the "ideal worker norm" (Pedulla, 2016), which could explain the negative relationship between FWE and job satisfaction.

Given that perceived supervisor support mediated the relationships between WFEDevelopment and job satisfaction, WFE-Affect and job satisfaction and FWE-Efficiency and job satisfaction, it is suggested that the mediating mechanisms leading from work-family enrichment to perceived supervisor support, and subsequently from perceived supervisor support to job satisfaction, are both affective (emotions) and instrumental (skills and abilities) for social workers. When social workers experience WFE-Development and WFE-Affect, they are essentially gaining skills and knowledge and experiencing positive moods and attitudes at work. The social exchange theory explains that social workers will attribute these positive experiences to the originating domain (the work domain), which leads to a positive affective appraisal of one's job experiences, such as feeling supported by their supervisors (perceived supervisor support), and, ultimately, a positive affective appraisal of one's job (job satisfaction). FWE-Efficiency represents the resource gains of time and efficiency (Greenhaus and Powell, 2006) and is indicative of the degree of flexibility in family responsibility (Carlson et al., 2006). This study's findings further indicate that social workers who experienced FWE-Efficiency also perceived their supervisors to be less supportive, and in turn achieved lower job satisfaction. Although Hobfoll's (2001) COR theory suggests that individuals who possess resources tend to be more focused on acquiring more resources (e.g. perceiving their supervisors to be supportive or experiencing job satisfaction), as they do not need to set aside resources to prevent further resource losses, we speculate that the work procedures that these social workers are expected to follow might be incongruent with what FWE-Efficiency offers, which in turn lowers their job satisfaction.

Although not investigated in the present study, culture as a part of the person and environment can influence how work- and family-related stressors are perceived and the responses an individual might have (Beehr and Glazer, 2001). Australia is low on power distance, and communication between managers and employees is informal, direct and
Enhancing job satisfaction through work

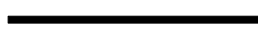


participative (Ashkanasy, 2007), which could be another reason why the current sample of social workers perceived their supervisors to be supportive, particularly in the presence of WFE-Affect and FWE-Efficiency. Positive resources such as WFE-Affect and FWEEfficiency also promote positive emotions, which reduce social workers' stress and assist them to cope with adversities (Collins, 2007). Specifically, positive emotions tend to ameliorate negative emotions and encourage people to reach out to others in their work and family domains for social support (Collins, 2007). Hence, future studies examining the job satisfaction of social workers should also consider their work environment (e.g. co-workers and supervisors) and entire family system (e.g. family members), as these people may exhibit behaviours that enhance or reduce social workers' abilities to perform on their jobs.

By contrast, while social workers valued resources such as WFE-Capital, FWEDevelopment and FWE-Affect, all of which were positively related to job satisfaction, these resources did not lead to perceived supervisor support. In their work-home resources model, which was informed by both the theory of work-family enrichment and COR theory, ten Brummelhuis and Bakker (2012) distinguished between short- and long-term resources. They suggest that structural personal resources, such as abilities, knowledge and accomplishments, take time to develop. This could possibly explain why WFE-Capital and FWE-Development were not associated with perceived supervisor support, as the latter is a more transient personal resource. Correspondingly, future studies are encouraged to examine the work-family experiences and work and non-work outcomes of social workers to adopt a time-lagged study design, as these resource-based processes tend to occur over time. Lastly, based on the social exchange theory, it is likely that FWE-Affect was not related to perceived supervisor support because the originating domain is the family domain; hence, social workers would most probably attribute the positive affect to their experiences at home, rather than to those at work.

\section{Practical implications}

This study, together with the emerging research on the work-family experiences of social workers, suggests that looking for ways to facilitate work-family enrichment among social workers can contribute to positive work outcomes such as perceived supervisor support and job satisfaction. Specifically, HR practitioners, supervisors and organisations are in unique positions to encourage work-family enrichment among social workers. Organisations can explore other work arrangements (e.g. part-time or flexible working arrangements) and means for improving work-family enrichment for social workers. For example, McNall et al. (2009) found that the availability of flexitime and compressed workweek schedules was a key driver of enrichment, which in turn increased job satisfaction. Additionally, supervisors and organisations should look into reducing long working hours. In this study, the control variable, number of hours worked per week, was shown to be negatively related to WFEDevelopment, WFE-Affect, FWE-Affect and FWE-Efficiency, which indicates that long working hours inhibited the enrichment process.

Although work resources were not directly measured, this study highlights the importance of resources that are part and parcel of the WFE and FWE processes (Greenhaus and Powell, 2006). Correspondingly, supervisors should work closely with social workers on their daily priorities and understand where their stress is coming from. In return, social workers will feel supported and satisfied with their job experiences. For example, supervisors can allocate more resources to particularly "hard" cases so that social workers do not feel unduly burdened by the intensity of their jobs. Breaking up work tasks, having microbreaks or reducing the number of difficult cases handled by each social worker also helps to ensure that the rewarding aspects of social work are interwoven better with the stressful aspects (Lee et al., 2015). 
Creating a supportive work-family friendly environment for social workers is another way to begin the resource generation process through WFE. This can be done through increasing the level of workplace flexibility for social workers, which enables them to better meet both their work and family demands (McNall et al., 2009). The significant positive relationships among work-family enrichment, perceived supervisor support and job satisfaction also signal to managers the importance of valuing social workers' family lives because family can be an important source of support for workers' job satisfaction. Apart from reconceptualising organisational structure and design to incorporate the work-family interface, work design that includes male and female social workers' inputs should be encouraged at all levels within the organisation and social workers' associations (Acker, 2006).

Given the importance of positive emotions in the enrichment process, it is also recommended that universities and organisations incorporate programmes and courses on resilience and coping techniques for social work students and professionals (Coffey et al., 2014). These programmes can focus on methods to manage stressful experiences and encourage participants to consider alternative ways of perceiving and coping with adversities (e.g. viewing challenges as opportunities for improvement, thereby turning demands into resources). Such interventions are shown to improve job satisfaction and the timely use of social support (Baral and Bhargava, 2010). Importantly, such interventions should be implemented by HR practitioners on a regular basis, as positive emotions can also be enhanced vicariously through observing other people's positive feelings and behaviours. At the same time, supervisors are encouraged to foster a sense of belonging by making sure that social workers have regular interactions with one another. Positive interactions at work, coupled with a sense of belonging, generate positive emotions, increase employee engagement and buffer the negative effects of stress (Dollard and Bakker, 2010). Social workers can also identify ways to improve their work and family conditions with strategies such as regular exercise and relaxation techniques that can help them build personal resources to overcome challenges.

\section{Strengths, limitations and recommendations for future research}

Although the mediation analysis in the present study was conducted at one time point and the findings are based on self-report data, the large sample lends confidence to the findings. The use of theoretical knowledge to explain the underlying mediation mechanism, as well as the advanced CFA and SEM fit indices used in the present study, the study findings provide reliable information about the associations between work-family enrichment, perceived supervisor support and job satisfaction. Nevertheless, given the paucity of longitudinal studies in the work-family literature (Casper et al., 2007) and the fact that some resources can only be built over time (Hobfoll, 2002), future studies using longitudinal data would be useful to test for causality.

To date, the use of Carlson et al.'s (2006) six-dimensional work-family enrichment measure remains limited. Few studies have examined all six dimensions (McNall et al., 2010); hence, more research using this measure is needed to enable a comparison of findings and to advance the theory of work-family enrichment. Future studies can also include other variables not examined in the present study. For example, perceived family support or co-worker support may have accounted for some of the effects. Studies such as the work by Judge and Bono (2001) have also found that personality traits are significantly correlated with job satisfaction. Therefore, including dispositional variables in future studies could enhance understanding of the enrichment-satisfaction relationship.

The limitations of this study are also acknowledged. The current sample was a convenience sample and subsequently excluded other potential participants. The use of an 
internet-based questionnaire in this study may have further limited the participation of individuals without reliable internet facilities. Additionally, the relatively low response rate in this sample limits the generalisability of the findings to all social workers. Lastly, the availability of resources might vary across groups of social workers in other countries, which may influence their perceptions of supervisor support. Thus, an extension of this study in other less studied countries is necessary.

\section{Conclusion}

While involvement in work provides social workers with resources such as positive attitudes, emotions and moods, the current research supports the notion that involvement in the family domain is equally crucial for social workers to achieve job satisfaction. This study simultaneously modelled both WFE and FWE alongside perceived supervisor support and job satisfaction; thus, it presents a more comprehensive test of the social exchange and COR theories than is currently available in social work research set in the work-family interface.

Specifically, the present study used a large sample of social workers to explore the underlying relationship linking work-family enrichment to perceived supervisor support and, ultimately, job satisfaction. The hypothesised mediation model demonstrated that social workers who experienced WFE-Affect (affective pathway), as well as WFE-Development also felt supported by their supervisors, and subsequently achieved job satisfaction. However, those who experienced FWE-Efficiency (instrumental pathway) did not feel supported by their supervisors and also experienced less job satisfaction. The findings emphasise the importance of contextual resources (work-family enrichment) and personal resources (perceived supervisor support) to facilitate social workers' attainment of job satisfaction and are instrumental in assisting HR practitioners and supervisors to create work-family friendly environments for social workers.

\section{References}

Acker, J. (2006), "Inequality regimes: gender, class, and race in organizations", Gender \& Society, Vol. 20 No. 4, pp. 441-464.

Anderson, J.C. and Gerbing, D.W. (1988), "Structural equation modeling in practice: a review and recommended two-step approach", Psychological Bulletin, Vol. 103 No. 3, pp. 411-423.

Aryee, S., Srinivas, E.S. and Tan, H.H. (2005), "Rhythms of life: antecedents and outcomes of workfamily balance in employed parents", Journal of Applied Psychology, Vol. 90 No. 1, pp. 132-146.

Ashkanasy, N.M. (2007), "The Australian enigma”, in Chhokar, J.S., Brodbeck, F.C. and House, R.J. (Eds), Culture and Leadership Across the World: The GLOBE Book of In-Depth Studies of 25 Societies, Lawrence Erlbaum, Mahwah, NJ, pp. 299-333.

Au, W.C. and Ahmed, P.K. (2016), "Relationships between superior support, work role stressors and work-life experience", Personnel Review, Vol. 45 No. 4, pp. 782-803.

Australian Bureau of Statistics (2016), "Labour Force, Australia, Detailed, Quarterly", available at: http://www.abs.gov.au/ausstats/abs@.nsf/mf/6291.0.55.003 (accessed February 2016).

Baral, R. and Bhargava, S. (2010), "Work-family enrichment as a mediator between organisational interventions for work-life balance and job outcomes", Journal of Managerial Psychology, Vol. 25 No. 3, pp. 274-300.

Baron, R.M. and Kenny, D.A. (1986), "The moderator-mediator variable distinction in social psychological research: conceptual, strategic, and statistical considerations", Journal of Personality and Social Psychology, Vol. 51 No. 5, pp. 1173-1182.

Baum, N. (2016), "Work-family conflict among social workers, managers and policy makers in times of disaster", British Journal of Social Work, Vol. 46 No. 1, pp. 222-238. 
Beddoe, L., Karvinen-Niinikoski, S., Ruch, G. and Tsui, M.S. (2015), "Towards an international consensus on a research agenda for social work supervision: report on the first survey of a Delphi study”, British Journal of Social Work, Vol. 46 No. 6, pp. 1568-1586.

Beehr, T.A. and Glazer, S. (2001), "A cultural perspective of social support in relation to occupational stress", in Perrewé, P., Ganster, D.C. and Moran, J. (Eds.), Research in Occupational Stress and Well-Being, JAI Press, Greenwich, CT, pp. 97-142.

Blau, P. (1964), Exchange and Power in Social Life, Wiley, New York, NY.

Calitz, T., Roux, A. and Strydom, H. (2014), "Factors that affect social workers' job satisfaction, stress and burnout", Social Work, Vol. 50 No. 1, pp. 153-169.

Caplan, R.D., Cobb, S., French, J.R.P.J., Harrison, R.V. and Pinneau, S.R. (1980), Job Demands and Worker Health: Main Effects and Occupational Differences, University of Michigan Institute for Social Research, Ann Arbor, MI.

Carlson, D.S., Kacmar, K.M., Wayne, J.H. and Grzywacz, J.G. (2006), "Measuring the positive side of the work-family interface: development and validation of a work-family enrichment scale", Journal of Vocational Behavior, Vol. 68 No. 1, pp. 131-164.

Carlson, D.S., Hunter, E.M., Ferguson, M. and Whitten, D. (2014), "Work-family enrichment and satisfaction: mediating processes and relative impact of originating and receiving domains", Journal of Management, Vol. 40 No. 3, pp. 845-865.

Casper, W.J., Eby, L.T., Bordeaux, C., Lockwood, A. and Lambert, D. (2007), “A review of research methods in IO/OB work-family research", Journal of Applied Psychology, Vol. 92 No. 1, pp. $28-43$.

Chan, X.W., Kalliath, T., Brough, P., Siu, O.L., O'Driscoll, M.P. and Timms, C. (2016), "Workfamily enrichment and satisfaction: the mediating role of self-efficacy and work-life balance", The International Journal of Human Resource Management, Vol. 27 No. 15, pp. 1755-1776.

Cheng, T., Mauno, S. and Lee, C. (2014), "Do job control, support, and optimism help job insecure employees? A three-wave study of buffering effects on job satisfaction, vigor and work-family enrichment”, Social Indicators Research, Vol. 118 No. 3, pp. 1269-1291.

Cheung, M.W.L. (2009), "Comparison of methods for constructing confidence intervals of standardized indirect effects", Behavior Research Methods, Vol. 41 No. 2, pp. 425-438.

Cinamon, R.G. and Rich, Y. (2010), "Work family relations: antecedents and outcomes", Journal of Career Assessment, Vol. 18 No. 1, pp. 59-70.

Coffey, M., Samuel, U., Collins, S. and Morris, L. (2014), “A comparative study of social work students in India and the UK: stress, support and well-being”, British Journal of Social Work, Vol. 44 No. 1, pp. 163-180.

Collins, S. (2007), "Social workers, resilience, positive emotions and optimism", Practice: Social Work in Action, Vol. 19 No. 4, pp. 255-269.

Collins, S. (2008), "Statutory social workers: stress, job satisfaction, coping, social support and individual differences", British Journal of Social Work, Vol. 38 No. 6, pp. 1173-1193.

Dollard, M.F. and Bakker, A.B. (2010), "Psychosocial safety climate as a precursor to conducive work environments, psychological health problems, and employee engagement", Journal of Occupational and Organisational Psychology, Vol. 83 No. 3, pp. 579-599.

Eagly, A.H. and Wood, W. (2016), "Social role theory of sex differences", in Naples, N.A., Hoogland, R.C., Wickramasinghe, M. and Wong, A.W.C. (Eds.), The Wiley Blackwell Encyclopedia of Gender and Sexuality Studies, Wiley, Hoboken, NJ.

Egan, M. and Kadushin, G. (2004), "Job satisfaction of home health social workers in the environment of cost containment", Health \& Social Work, Vol. 29 No. 4, pp. 287-296.

Freund, A. (2005), "Commitment and job satisfaction as predictors of turnover intentions among welfare workers", Administration in Social Work, Vol. 29 No. 2, pp. 5-21. 
Greenhaus, J.H. and Powell, G.N. (2006), "When work and family are allies: a theory of work-family enrichment", Academy of Management Review, Vol. 31 No. 1, pp. 72-92.

Griffin, M.A., Patterson, M.G. and West, M.A. (2001), "Job satisfaction and teamwork: the role of supervisor support”, Journal of Organizational Behavior, Vol. 22 No. 5, pp. 537-550.

Halbesleben, J.R., Neveu, J.P., Paustian-Underdahl, S.C. and Westman, M. (2014), "Getting to the "COR" understanding the role of resources in conservation of resources theory", Journal of Management, Vol. 40 No. 5, pp. 1334-1364.

Hammer, L.B., Cullen, J.C., Neal, M.B., Sinclair, R.R. and Shafiro, M.V. (2005), “The longitudinal effects of work-family conflict and positive spillover on depressive symptoms among dual-earner couples", Journal of Occupational Health Psychology, Vol. 10 No. 2, pp. 138-154.

Healy, K. and Lonne, B. (2010), The Social Work and Human Services Workforce: Report from a National Study of Education, Training and Workforce Needs, Australian Learning and Teaching Council, Strawberry Hills.

Henry, H. and Desmette, D. (2018), "Work-family enrichment and well-being: the role of occupational future time perspective”, Career Development International, Vol. 23 Nos 2/3, pp. 542-556.

Hobfoll, S.E. (1989), "Conservation of resources: a new attempt at conceptualizing stress", American Psychologist, Vol. 44 No. 3, pp. 513-524.

Hobfoll, S.E. (2001), "The influence of culture, community, and the nested-self in the stress process: advancing conservation of resources theory", Applied Psychology: An International Review, Vol. 50 No. 3, pp. 337-421.

Hobfoll, S.E. (2002), "Social and psychological resources and adaptation", Review of General Psychology, Vol. 6 No. 4, pp. 307-324.

Hu, L.T. and Bentler, P.M. (1999), "Cutoff criteria for fit indexes in covariance structure analysis: conventional criteria versus new alternatives", Structural Equation Modeling: A Multidisciplinary Journal, Vol. 6 No. 1, pp. 1-55.

Hughes, J.M. (2010), "The role of supervision in social work: a critical analysis", Critical Social Thinking, Policy and Practice, Vol. 2, pp. 59-77.

Huxley, P., Evans, S., Gately, C., Webber, M., Mears, A., Pajak, S., Kenddall, T., Medina, J. and Katona, C. (2005), "Stress and pressures in mental health social work: the worker speaks", British Journal of Social Work, Vol. 35 No. 7, pp. 1063-1079.

Judge, T.A. and Bono, J.E. (2001), "Relationship of core self-evaluations traits-self-esteem, generalized self-efficacy, locus of control, and emotional stability - with job satisfaction and job performance: a meta-analysis", Journal of Applied Psychology, Vol. 86 No. 1, pp. 80-92.

Kalliath, P. (2014), "Is work-family enrichment an antidote to experiences of psychological strain among Australian social workers? An empirical study", Australian Social Work, Vol. 67 No. 3, pp. 332-347.

Kalliath, P. and Kalliath, T. (2015), "Work-family conflict and its impact on job satisfaction of social workers", British Journal of Social Work, Vol. 45 No. 1, pp. 241-259.

Kalliath, P., Kalliath, T. and Chan, C. (2015), "Work-family conflict and family-work conflict as predictors of psychological strain: does social support matter?”, British Journal of Social Work, Vol. 45 No. 8, pp. 2387-2405.

Kalliath, P., Kalliath, T., Chan, X.W. and Chan, C. (2019), "Linking work-family enrichment to job satisfaction through job well-being and family support: a moderated mediation analysis of social workers across India”, British Journal of Social Work, Vol. 49 No. 1, pp. 234-255.

Kossek, E.E. (2015). "Foreword", in Mills, M. (Eds), Gender and the Work-Family Experience: An Intersection of Two Domains, Springer, Hempstead, New York, NY, p. 8.

Kossek, E.E., Baltes, B.B. and Matthews, R.A. (2011), "How work-family research can finally have an impact in organisations", Industrial and Organisational Psychology, Vol. 4 No. 3, pp. 352-369. 
Lambert, E., Pasupuleti, S., Cluse-Tolar, T., Jennings, M. and Baker, D. (2006), “The impact of workfamily conflict on social work and human service worker job satisfaction and organisational commitment: an exploratory study", Administration in Social Work, Vol. 30 No. 3, pp. 55-74.

Lee, K.E., Williams, K.J., Sargent, L.D., Williams, N.S. and Johnson, K.A. (2015), "40-second green roof views sustain attention: the role of micro-breaks in attention restoration", Journal of Environmental Psychology, Vol. 42, pp. 182-189.

Lloyd, C., King, R. and Chenoweth, L. (2002), "Social work, stress and burnout: a review”, Journal of Mental Health, Vol. 11 No. 3, pp. 255-265.

Locke, E.A. (1976), "The nature and causes of job satisfaction”, in Dunnette, M.D. (Ed.), Handbook of Industrial and Organisational Psychology, Rand McNally, Chicago, IL, pp. 1297-1349.

Marks, S.R. (1977), "Multiple roles and role strain: some notes on human energy, time and commitment", American Sociological Review, Vol. 42 No. 6, pp. 921-936.

McNall, L.A., Masuda, A.D. and Nicklin, J.M. (2009), "Flexible work arrangements, job satisfaction, and turnover intentions: the mediating role of work-to-family enrichment", The Journal of Psychology, Vol. 144 No. 1, pp. 61-81.

McNall, L.A., Nicklin, J.M. and Masuda, A. (2010), "A meta-analytic review of the consequences associated with work-family enrichment”, Journal of Business and Psychology, Vol. 25 No. 3, pp. 381-396.

Oerlemans, W.G., Bakker, A.B. and Demerouti, E. (2014), "How feeling happy during off-job activities helps successful recovery from work: a day reconstruction study", Work \& Stress, Vol. 28 No. 2, pp. 198-216.

Offer, S. and Schneider, B. (2008), "The emotional dimensions of family time and their implications for work-family balance”, in Korabik, K., Lero, D.S. and Whitehead, D.L. (Eds.), Handbook of Work-Family Integration, Academic Press, London, pp. 177-189.

O'Driscoll, M. (2000), "Work and family transactions", in Koopman-Boyden, P., Dharmalingam, A., Grant, B., Hendy, V., Hillcoat-Nalletamby, S., Mitchell, D., O'Driscoll, M. and Thompson, S. (Eds.), Transactions in the Mid-Life Family, Population Association of New Zealand, Hamilton, pp. 91-112.

Pedulla, D.S. (2016), "Penalized or protected? Gender and the consequences of nonstandard and mismatched employment histories", American Sociological Review, Vol. 81 No. 2, pp. 262-289.

Preacher, K.J. and Hayes, A.F. (2008), "Asymptotic and resampling strategies for assessing and comparing indirect effects in multiple mediator models", Behavior Research Methods, Vol. 40 No. 3, pp. 879-891.

Rastogi, M. and Chaudhary, R. (2019), "Job crafting and work-family enrichment: the role of positive intrinsic work engagement", Personnel Review, Vol. 47 No. 3, pp. 651-674.

Rathi, N. and Lee, K. (2017), "Understanding the role of supervisor support in retaining employees and enhancing their satisfaction with life", Personnel Review, Vol. 46 No. 8, pp. 1605-1619.

Rogerson, R. (2006), "Understanding differences in hours worked", Review of Economic Dynamics, Vol. 9 No. 3, pp. 365-409.

Saari, L.M. and Judge, T.A. (2004), "Employee attitudes and job satisfaction", Human Resource Management, Vol. 43 No. 4, pp. 395-407.

Schwartz, A. (2007), "How goal orientation match between social workers and their supervisors impacts social workers' job satisfaction: a theoretical exploration”, The Clinical Supervisor, Vol. 26 Nos 1-2, pp. 223-237.

Seashore, L., Lawler, E., Marvis, P. and Cammann, C. (1982), Observing and Measuring Organisational Change: A Guide to Field Practice, Wiley, New York, NY.

Shanock, L.R. and Eisenberger, R. (2006), "When supervisors feel supported: relationships with subordinates' perceived supervisor support, perceived organisational support, and performance", Journal of Applied Psychology, Vol. 91 No. 3, pp. 689-695.
Enhancing job satisfaction through work

\section{(r)}


Sieber, S.D. (1974), "Toward a theory of role accumulation", American Sociological Review, Vol. 39 No. 4, pp. 567-578.

Siu, O.L., Lu, J.F., Brough, P., Lu, C.Q., Bakker, A.B., Kalliath, T., O’Driscoll, M., Phillips, D.R., Chen, W., Lo, D. and Shi, C.S.K. (2010), "Role resources and work-family enrichment: the role of work engagement”, Journal of Vocational Behavior, Vol. 77 No. 3, pp. 470-480.

ten Brummelhuis, L.L. and Bakker, A.B. (2012), "A resource perspective on the work-home interface: the work-home resources model”, American Psychologist, Vol. 67 No. 7, pp. 545-556.

Ullman, J.B. (2001), "Structural equation modeling", in Tabachnick, B.G. and Fidell, L.S. (Eds.), Using Multivariate Statistics, 4th ed., Allyn \& Bacon, Needham Heights, MA, pp. 653-771.

Wayne, J.H., Grzywacz, J.G., Carlson, D.S. and Kacmar, K.M. (2007), "Work-family facilitation: a theoretical explanation and model of primary antecedents and consequences", Human Resource Management Review, Vol. 17 No. 1, pp. 63-76.

Williams, J. (2001), Unbending Gender: Why Family and Work Conflict and What to Do About It, Oxford University Press, Oxford.

\section{Corresponding author}

Parveen Kalliath can be contacted at: parveen.kalliath@acu.edu.au

For instructions on how to order reprints of this article, please visit our website: 